\title{
STUDY OF HISTOPATHOLOGICAL CHANGES IN LIVER AND ADRENALS FOLLOWING DEATH DUE TO BURNS AT VARYING PERIODS OF SURVIVAL
}

\author{
Sathikumar $M^{1}$
}

${ }^{1}$ Associate Professor, Department of Forensic Medicine, SUT Academy of Medical Sciences, Vattappara, Thiruvananthapuram.

ABSTRACT
BACKGROUND
The term 'burn' is applied more in lay than in medical circles to a variety of conditions, of which the local effects of dry heat
described in restrictive terms as burns. Flame burns are characterized by singeing of hairs and show a geographic distribution. In
the present study of the 60 cases, the death is due to the higher incidence of suicide by burns. The higher involvement of burn death
in females are due to the fact that more burn cases are reported and medico-legal autopsies are done on these cases to meet the legal
requirement. The two organs, liver and adrenals undergo marked histopathological changes. With this background, the present study
was planned to work out the histopathological changes of liver and adrenals following death due to burns at varying periods of
survival.

\section{MATERIALS AND METHODS}

The study was conducted at Government Medical College, Kozhikode, and during the period of one year, 60 cases of death due to burns from fire were studied.

\section{RESULTS}

In liver, the histopathological changes like portal oedema, portal haemorrhage and congestion, sinusoidal congestion, focal necrosis and inflammation and in adrenals, histopathological changes like cortical and medullary haemorrhage and oedema, focal necrosis, capsular haemorrhage and oedema were seen.

\section{DISCUSSION AND CONCLUSION}

Considering the histopathological changes of liver when the period of survival increases, liver undergoes moderate degree of changes and most of the people died along with early cirrhotic changes of liver, but when the period of survival increase adrenals undergo mild and moderate degree of changes and may lead to acute adrenal insufficiency and possible death. On conclusion from the study that liver and adrenals show constant histopathological changes in cases of death due to burns irre spective of the period of survival and these organs are more important in determining the cause of death.

\section{KEYWORDS}

Histopathological Changes, Survival, Severity, Burn.

HOW TO CITE THIS ARTICLE: Sathikumar M. Study of histopathological changes in liver and adrenals following death due to burns at varying periods of survival. J. Evolution Med. Dent. Sci. 2016;5(62):4356-4359, DOI: 10.14260/jemds/2016/994

\section{INTRODUCTION}

Throughout the history of man, fire has had a varied symbolic significance to him. Its use as a form of protest against the constraints and pressures of society has long been known.

The important aetiological factors behind the accidental burn death are careless handling of kerosene and cooking gas cylinders, bursting of stoves in kitchen, clothes accidentally catching fire while working in kitchen and rarely burns occurring during sleep in case of persons intoxicated by drug or alcohol, going to sleep with lighted cigarettes.

Copeland AR (1985) ${ }^{1}$, a study of self-immolation or suicidal fire deaths was performed on the case of files of the office of the Medical Examiner of Metropolitan Dade County in Miami, Florida. Majority of our day-to-day experiences are females.

Financial or Other, Competing Interest: None.

Submission 23-06-2016, Peer Review 18-07-2016,

Acceptance 23-07-2016, Published 03-08-2016.

Corresponding Author:

Dr. Sathikumar $M$,

Associate Professor

Department of Forensic Medicine,

SUT Academy of Medical Sciences,

Vattappara, Thiruvananthapuram.

E-mail: drsathikumar6@gmail.com

DOI: $10.14260 /$ jemds/2016/994
Strain and stress of modern life and dowry problems account for more number of suicidal deaths in case of females. According to Mason S, Hillier VF (1993) ${ }^{2}$, the thermal injury, personal and social factors affecting the short-term outcome responses of thermally injured children under five years age and their mothers are reported. The study has been undertaken to investigate the histopathological changes of liver and adrenals at various survival period. A total of 60 cases were studied and 51 subjects died with deep burns and the rest with superficial burns. Of this 7 subjects died immediately and rest had varied period of survival from 1 to 28 days.

\section{MATERIALS AND METHODS}

The duration of study was 1 year and was conducted at Government Medical College, Kozhikode. In the study, 60 cases of death due to burns from fire was studied during the period. Histopathological changes occurred in the organs (Liver and adrenals) of all the 60 cases were noted, the changes noted in these organs in the case of immediate deaths and subsequent deaths were noted and grouped into 6 grades according to the period of survival. In cases in which death was not immediate and being admitted to the hospital, the details of treatment were also noted after perusal of their case sheets. 


\section{OBSERVATION AND RESULTS}

During the period, 60 cases of burns deaths were studied. Of these 60 cases 39 deaths were suicidal comprising 65\%, 20 accidental comprising $33.33 \%$ and 1 case was homicidal constituting 1.67\% (Shown in Fig. 1).

Majority of subjects were females (46/60) comprising $76.67 \%$ of the subjects and rest were males (14/60) comprising 23.33\% (Shown in Fig. 2).

Regarding period of survival, of these 60 cases 7 subjects died immediately (11.67\%), i.e. brought dead cases, 17 subjects died within 1-hour to 24-hours (28.34\%); 21 subjects died within 1 day to 7 days (35\%), 11 subjects died within 8 days to 14 days (18.33\%), 2 subjects died within 15 days to 21 days (3.33\%) and 2 subjects died within 22 to 28 days (3.33\%) as shown in Table 1.

Histopathological changes of internal organs, liver and adrenals were studied at various period of survival and grouped into VI groups, i.e. changes during immediate death, changes during 1-hour to 24-hours, changes during 1 day to 7 days, 8 days to 14 days, during 15 days to 21 days and changes during 22 to 28 days of survival.

Depending upon the severity of the histopathological changes of the organs, again each organ changes were graded into Grade I (Mild degree changes), Grade II (Moderate degree of changes), Grade III (Severe degree of changes), Grade IV (Very severe degree of changes) shown in Table 2.

In the case of immediate death in Grade I, 1+ to 3+ were considered. In Grade II, 4+ to 6+ were considered. In Grade III, $7+$ to $9+$ and in Grade IV 10+ to $12+$ and above are considered. In the case of other five groups in Grade I $1+$ to $4+$, in Grade II 5+ to 8+, in Grade III 9+ to 12+ and in Grade IV 13+ to 16+ and above were considered.

Regarding histopathological organs, i.e. liver and adrenals, in case of immediate death, liver showed $71.42 \%$ of Grade I changes, $14.29 \%$ of Grade II and $14.29 \%$ of Grade IV changes; whereas adrenals showed $100 \%$ of Grade I changes only (As shown in Table 3). During the period of 1-hour to 24 hours histopathological changes of liver showed $58.82 \%$ of Grade I and $41.18 \%$ of Grade II changes (Photo 1 ).
In case of adrenals showed $88.24 \%$ of Grade I and $11.76 \%$ of Grade II changes (Table 4).

Considering the period of survival 1 day to 7 days, histopathological changes of liver showed $66.67 \%$ of Grade I changes and $33.33 \%$ of Grade II changes (Photo 2, Photo 3). While adrenals showed $80.95 \%$ of Grade I and $19.05 \%$ of Grade II changes (Photo 4) Table 5.

Regarding period of survival 8 to 14 days, histopathological changes of liver showed $72.73 \%$ of Grade I and $27.27 \%$ of Grade II changes, whereas adrenals showed $100 \%$ of Grade I changes (Table 6).

Histopathological changes of organs during the period of survival 15 to 21 days, liver showed $100 \%$ of Grade II changes and adrenals showed $50 \%$ of Grade I and $50 \%$ of Grade II changes (Table 7).

In case of histopathological changes of organs during the period of survival 22 to 28 days, liver showed $100 \%$ of Grade II changes, while adrenals showed $50 \%$ of Grade I and $50 \%$ of Grade II changes (Table 8).

\begin{tabular}{|c|c|c|}
\hline Period of Survival & Number & Percentage \\
\hline Immediate death & 7 & 11.67 \\
\hline 1 hour to 24 hours & 17 & 28.34 \\
\hline 1 day to 7 days & 21 & 35 \\
\hline 8 days to 14 days & 11 & 18.33 \\
\hline 15 days to 21 days & 2 & 3.33 \\
\hline 22 days to 28 days & 2 & 3.33 \\
\hline \multicolumn{2}{|c|}{ Table 1: Period of Survival } \\
\hline
\end{tabular}

\begin{tabular}{|c|l|}
\hline Organ & \multicolumn{1}{|c|}{ Histopathological Changes } \\
\hline Liver & $\begin{array}{l}\text { Portal oedema, Portal haemorrhage and } \\
\text { congestion, Sinusoidal congestion, Focal } \\
\text { necrosis, inflammation }\end{array}$ \\
\hline Adrenals & $\begin{array}{l}\text { Cortical and medullary haemorrhage and } \\
\text { oedema, Focal necrosis, Capsular haemorrhage } \\
\text { and oedema }\end{array}$ \\
\hline \multicolumn{2}{|c|}{ Table 2: Histopathological Changes } \\
\hline
\end{tabular}

\begin{tabular}{|c|c|c|c|c|c|c|c|c|}
\hline Organs & $\begin{array}{c}\text { Grade I } \\
\text { 1+ to 3+ } \\
\text { (Mild) }\end{array}$ & $\%$ & $\begin{array}{c}\text { Grade II } \\
\text { 4+ to 6+ } \\
\text { (Moderate) }\end{array}$ & $\%$ & $\begin{array}{l}\text { Grade III } \\
7+\text { to 9+ } \\
\text { (Severe) }\end{array}$ & $\%$ & $\begin{array}{c}\text { Grade IV } \\
10+\text { to } 12+\& \\
\text { Above } \\
\text { (Very Severe) }\end{array}$ & $\%$ \\
\hline Liver & 5 & 71.42 & 1 & 14.29 & 0 & 0 & 1 & 14.29 \\
\hline Adrenals & 7 & 100 & 0 & 0 & 0 & 0 & 0 & 0 \\
\hline
\end{tabular}

\begin{tabular}{|c|c|c|c|c|c|c|c|c|}
\hline Organs & $\begin{array}{c}\text { Grade I } \\
\text { 1+ to 3+ } \\
\text { (Mild) }\end{array}$ & $\%$ & $\begin{array}{c}\text { Grade II } \\
\text { 4+ to 6+ } \\
\text { (Moderate) }\end{array}$ & $\%$ & $\begin{array}{l}\text { Grade III } \\
7+\text { to } 9+ \\
\text { (Severe) }\end{array}$ & $\%$ & $\begin{array}{c}\text { Grade IV } \\
10+\text { to } 12+\& \\
\text { Above } \\
\text { (Very Severe) }\end{array}$ & $\%$ \\
\hline Liver & 10 & 58.82 & 7 & 41.18 & 0 & 0 & 0 & 0 \\
\hline Adrenals & 15 & 88.24 & 2 & 11.76 & 0 & 0 & 0 & 0 \\
\hline
\end{tabular}

\begin{tabular}{|c|c|c|c|c|c|c|c|c|}
\hline Organs & $\begin{array}{c}\text { Grade I } \\
\text { 1+ to 3+ } \\
\text { (Mild) }\end{array}$ & $\%$ & $\begin{array}{c}\text { Grade II } \\
\text { 4+ to 6+ } \\
\text { (Moderate) }\end{array}$ & $\%$ & $\begin{array}{l}\text { Grade III } \\
7+\text { to 9+ } \\
\text { (Severe) }\end{array}$ & $\%$ & $\begin{array}{c}\text { Grade IV } \\
10+\text { to } 12+\& \\
\text { Above } \\
\text { (Very Severe) }\end{array}$ & $\%$ \\
\hline Liver & 14 & 66.67 & 7 & 33.33 & 0 & 0 & 0 & 0 \\
\hline Adrenals & 17 & 80.95 & 4 & 19.05 & 0 & 0 & 0 & 0 \\
\hline
\end{tabular}




\begin{tabular}{|c|c|c|c|c|c|c|c|c|}
\hline Organs & $\begin{array}{c}\text { Grade I } \\
\text { 1+ to 3+ } \\
\text { (Mild) }\end{array}$ & $\%$ & $\begin{array}{c}\text { Grade II } \\
\text { 4+ to 6+ } \\
\text { (Moderate) }\end{array}$ & $\%$ & $\begin{array}{l}\text { Grade III } \\
7+\text { to } 9+ \\
\text { (Severe) }\end{array}$ & $\%$ & $\begin{array}{c}\text { Grade IV } \\
\text { 10+ to 12+ \& Above } \\
\text { (Very Severe) }\end{array}$ & $\%$ \\
\hline Liver & 8 & 72.73 & 3 & 27.27 & 0 & 0 & 0 & 0 \\
\hline Adrenals & 11 & 100 & 0 & 0 & 0 & 0 & 0 & 0 \\
\hline
\end{tabular}

\begin{tabular}{|c|c|c|c|c|c|c|c|c|}
\hline Organs & $\begin{array}{c}\text { Grade I } \\
\text { 1+ to 3+ } \\
\text { (Mild) }\end{array}$ & $\%$ & $\begin{array}{c}\text { Grade II } \\
\text { 4+ to 6+ } \\
\text { (Moderate) }\end{array}$ & $\%$ & $\begin{array}{c}\text { Grade III } \\
\text { (Severe) }\end{array}$ & $\begin{array}{c}\text { Grade IV } \\
\text { 10+ to 12+ \& } \\
\text { Above } \\
\text { (Very Severe) }\end{array}$ & $\begin{array}{c}\% \\
0\end{array}$ \\
\hline Liver & 0 & 0 & 2 & 100 & 0 & 0 & 0 & 0 \\
\hline Adrenals & 1 & 50 & 1 & 50 & 0 & 0 & 0 \\
\hline
\end{tabular}

\begin{tabular}{|c|c|c|c|c|c|c|c|c|}
\hline Organs & $\begin{array}{c}\text { Grade I } \\
\text { 1+ to 3+ } \\
\text { (Mild) }\end{array}$ & $\%$ & $\begin{array}{c}\text { Grade II } \\
\text { 4+ to 6+ } \\
\text { (Moderate) }\end{array}$ & $\%$ & $\begin{array}{c}\text { Grade III } \\
\text { (Severe) }\end{array}$ & $\begin{array}{c}\text { Grade IV } \\
\mathbf{1 0 +} \text { to12+ \& } \\
\text { Above } \\
\text { (Very Severe) }\end{array}$ & $\begin{array}{c}\% \\
0\end{array}$ \\
\hline Liver & 0 & 0 & 2 & 100 & 0 & 0 & 0 & 0 \\
\hline Adrenals & 1 & 50 & 1 & 50 & 0 & 0 & 0 \\
\hline
\end{tabular}

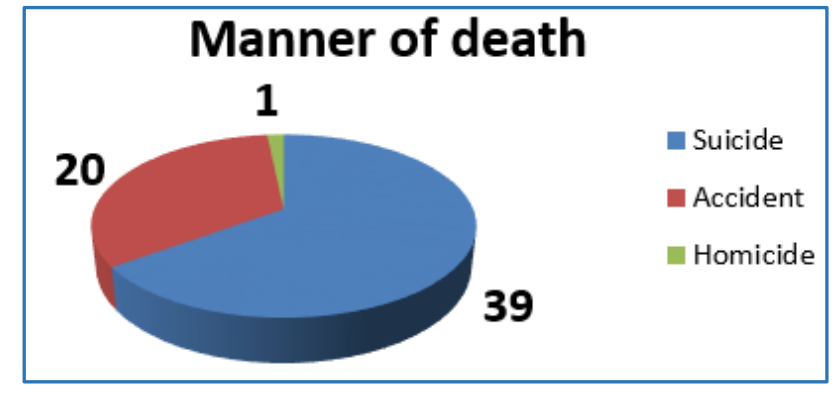

Fig. 1

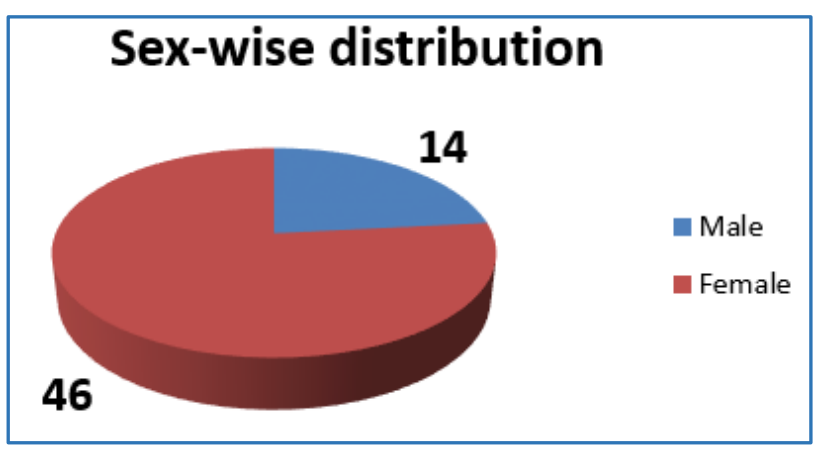

Fig. 2

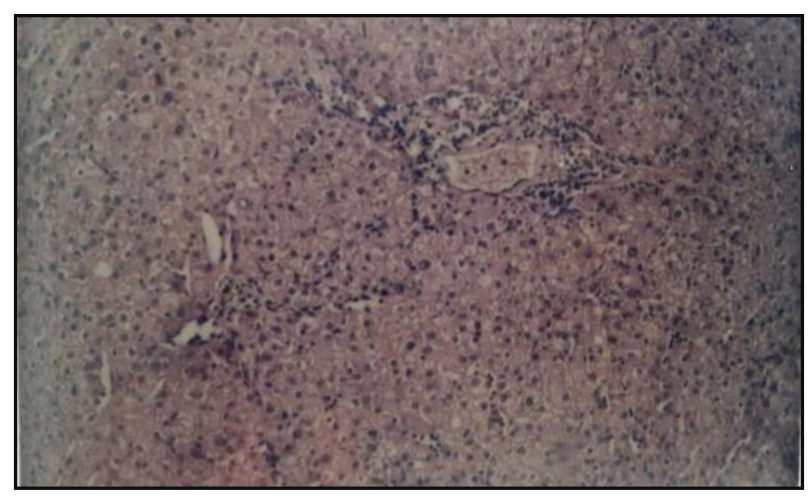

Photo 1: Period of Survival 2 Hours. Liver showing Portal Inflammation, Sinusoidal Congestion and Focal Hepatocellular Necrosis

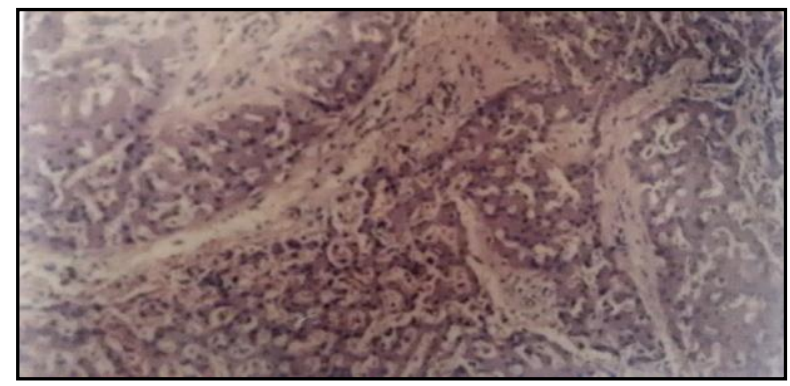

Photo 2: Period of Survival 2 Days 12 Hours. Liver showing Thick Bundles of Fibrous Tissue with Minimal Inflammation

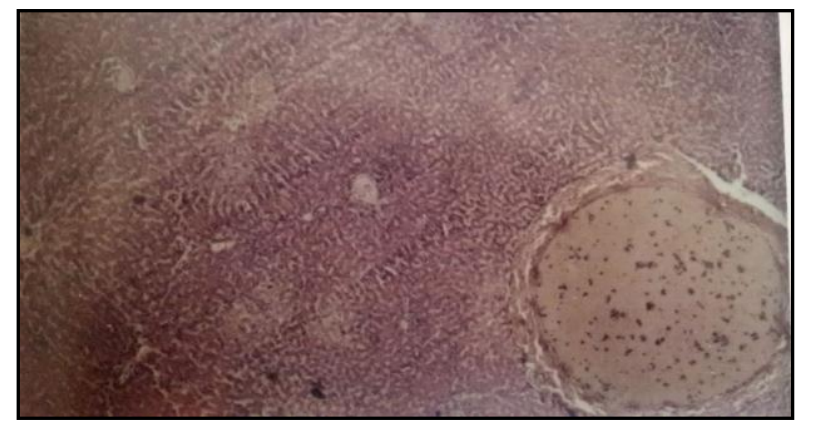

Photo 3: Period of Survival 3 Days 9 Hours. Liver showing a Dilated Venous Channel Containing Oedematous Fluid and Minimal Inflammation in Portal Triad

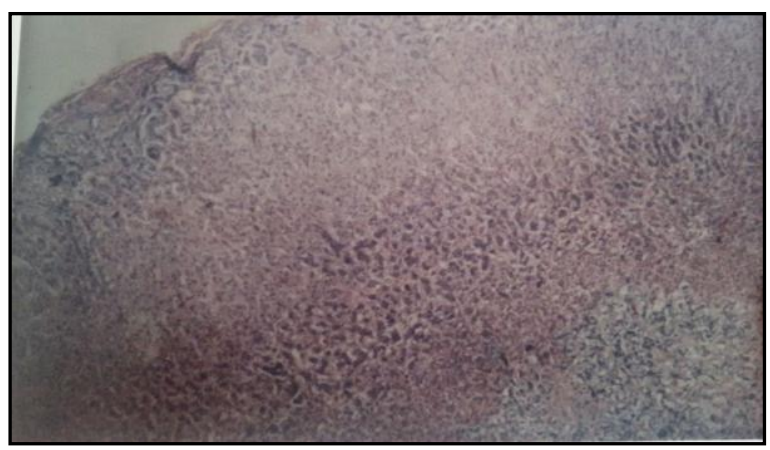

Photo 4: Period of Survival 3 Days. Adrenal showing Cortical Haemorrhage and Congestion (Moderate) 


\section{DISCUSSION}

In this study, histopathological changes of various internal organs like liver and adrenals in burn deaths during different period of survival were studied. Of these sixty cases, 7 subjects died immediately. Histopathological study of liver showed $71.42 \%$ of Grade I, i.e. mild degree changes of portal oedema and haemorrhage, necrosis and sinusoidal congestion and the rest of the percentage showed $14.29 \%$ of Grade II (Moderate degree) and $14.29 \%$ of Grade IV of liver changes, i.e. Very severe degree changes of portal oedema, haemorrhage and sinusoidal congestion. According to Rink RD et al (1985). ${ }^{3}$ stagnant hypoxia has been suggested as a significant factor underlying acute liver disease following thermal injury; whereas adrenals showed $100 \%$ changes of Grade I, i.e. mild degree of cortical and medullary haemorrhage, oedema, focal necrosis and capsular haemorrhage. These findings are due to acute adrenal insufficiency as stated by Murphy JF et al (1993). ${ }^{4}$

During the period of survival, 1 hour to 24 hours, liver show $58.82 \%$ of Grade I histopathological changes and the rest of the percentage showed Grade II changes. These findings are similar to the study of Czaja et al (1975), and states that hepatic dysfunction occurs early during the post injury curse in approximately $60 \%$ of burn patients. Zaets TL (1983). ${ }^{5}$ studied the structural and enzymatic disorganization of biological membranes in rat liver cells in thermal burns and found that permeability of cell and lysosomal membranes was demonstrated to be disordered within the first hours after burn.

Adrenal changes include $82.24 \%$ of Grade I and rest of the percentage showed Grade II changes, i.e. mild and moderate degree of cortical medullary haemorrhage and oedema and capsular haemorrhage.

Similar to study of J. B. Walter and I. C. Talbot (1996), ${ }^{6}$ adrenal necrosis sometimes accompanied by haemorrhage may complicate shock and acute adrenal insufficiency may contribute to death.

During the period of survival 1 day to 7 days of burns death, liver showed $66.67 \%$ of Grade I mild degree changes like portal haemorrhage, congestion and sinusoidal congestion. Similar to study of Chen YS, Li N et al (1985). ${ }^{7}$ The rest of the percentage includes Grade II changes. Here adrenals showed $80.95 \%$ of Grade I and rest of the percentage showed Grade II changes, i.e. more percentage of mild degree cortical and medullary haemorrhage oedema and capsular haemorrhage. Vijay Kumar et al found adrenal haemorrhage in $27.5 \%$ of cases of death due to burn.

Regarding period of survival, 8 days to 14 days, histopathological study of liver showed $72.73 \%$ of Grade I changes slightly higher than the period of study of 1 to 7 days, rest of the changes belongs to Grade II changes. These findings are similar to study of Lanlinais PC, Panke TW (1979). ${ }^{8}$

In case of adrenals showed $100 \%$ of Grade I mild degree changes.

During the period of survival, 15 days to 21 days, histopathological changes of liver undergoes $100 \%$ of Grade II (Moderate degree changes). But adrenal changes are 50\% each of Grade I and Grade II changes. Findings as stated Saakov BA, Bardakhch'ian EA (1978). ${ }^{9}$

Lastly during the period of survival, 22 days to 28 days, histopathological study of liver showed $100 \%$ of Grade II changes (Moderate degree) and adrenals showed 50\% each of
Grade I and Grade II. These findings are due to adrenal insufficiency as stated by Murphy JF et al (1993) and Hesman Y, Rentzhog L et al (1976). ${ }^{10}$

From this study the histopathological changes of liver Grade I, i.e. mild degree changes are more prominent in the early period of survival and during the immediate death; whereas when the period of survival increased from above two weeks, liver undergoes moderate degree of changes and most of the people died along with early cirrhotic changes of liver.

At various period of survival, adrenal changes are limited to mild and moderate degree. In immediate death and at early period of survival, adrenal undergoes mild degree changes. But when period of survival increased, adrenals undergoes mild and moderate degree of changes. Thus when the period of survival increased the intensity and degree of changes of adrenals varied in burns and people died due to acute adrenal insufficiency.

\section{INFERENCE}

From this study, it is concluded that the histopathological changes of liver and adrenals are varied at varying period of survival in burns. The severity of histopathological changes was predominant in the early periods of survival of burn deaths and there was no commendable increase in the severity of changes with increase in the period of survival. Since the most common cause of death is due to early cirrhotic changes of liver and acute adrenal insufficiency, it may be possible that if more aggressive therapeutic measures are taken to give care to these two organs probably more lives can be saved.

\section{REFERENCES}

1. Copeland AR. Suicidal fire deaths revisited. Z Rechtsmed 1985;95(1):51-7.

2. Mason S, Hillier VF. Young scarred children and their mothers-a short-term investigation into the practical, psychological and social implications of thermal injury to the preschool child. Burns 1993;19(6):501-6.

3. Rink RD, Dew KD, Campbell FR. Effects of scald injury on hepatic $\mathrm{PO}_{2}$, blood flow and ultrastructure in the rat. Circ shock 1985;17(1):73-84.

4. Murphy JF, Purdue GF, Hunt JL. Acute adrenal insufficiency in the patient with burns. J Burn Care Rehabil 1993;14(2 Pt 1):155-7.

5. Zaets TL. Structural and enzymatic disorganization of biological membranes in rat liver cells in thermal injury. Biull Eksp Biol Med 1983;96(10):43-5.

6. Walter JB, Talbot IC. General pathology. $7^{\text {th }}$ ed. Chapter 32, Published by Abe Books 1996:580.

7. Chen YS, Li N, Shi JQ, et al. Histopathological and ultrastructural change in liver tissue from burned patients. Bruns Incl Therm Inj 1985;11(6):408-18.

8. Langlinais PC, Panke TW. Intrasinusoidal bodies in the livers of thermally injured patients. Arch Pathol Lab Med 1979;103(10):499-504.

9. Saakov BA, Bardakhch'ian EA. Ultrastructure of the adrenal medullar and blood catecholamine levels after exposure to thermal injury. Buill Eksp Biull Med 1978;85(6):760-5.

10. Hesman Y, Rentzhog L, Ekbohm G. Effect of adrenal demedullation on urinary excretion of catecholamines in thermal trauma in rats. Acta Chir Scand 1976;142(4): 291-5. 